\title{
GAMBARAN KALKULUS PADA MASYARAKAT PESISIR YANG MENGONSUMSI AIR SUMUR GALI DI DESA GANGGA II
}

\author{
${ }^{1}$ Wanda S. Wungkana \\ ${ }^{2}$ Billy J. Kepel \\ ${ }^{2}$ Dinar A. Wicaksono
}

\author{
${ }^{1}$ Kandidat Skrispi Program Studi Pendidikan Dokater Gigi Fakultas Kedokteran \\ Universitas Sam Ratulangi \\ ${ }^{2}$ Program Studi Pendidikan Dokter Gigi Fakultas Kedokteran Universitas Sam Ratulangi \\ Email: Wandawuu02@gmail.com
}

\begin{abstract}
Calculus is a collection and calssification of plaque that had attached to surface of the teeth as well as other solid object in the mouth, consequently can cause periodontal tissues damage. Dug well water contain such as calcium and phosphorous which are ingredients in the formation of calculus. This research was conducted to description calculus on coastal communities that consume dug well water in Gangga II kecamatan Likupang Barat kabupaten Minahasa Utara. This research is a descriptive study with a cross-sectional study approach. Sampling using simple random sampling with number of sample 272 responden whom still consume dug well water as the main source of drinking water. Research data stratified by age group, sex, and index calculus. Results of calculus status in Gangga II with good category were 176 people $(64,70 \%)$, moderate category were 88 people $(32,35 \%)$ and bad category were 8 people $(2,94 \%)$. Based on the result showed the incidence of calculus on the population of Gangga II were good.
\end{abstract}

Keywords: Calculus, water wells dug.

\begin{abstract}
Abstrak: Kalkulus merupakan kumpulan plak yang mengalami kalsifikasi dan melekat erat pada permukaan gigi serta objek solid lainnya di dalam mulut, akibatnya dapat menyebabkan terjadinya kerusakan jaringan penyangga gigi. Air sumur gali memiliki kandungan seperti kalsium dan fosfor yang juga merupakan kandungan dalam pembentukan kalkulus. Penelitian ini dilakukan untuk mengetahui gambaran kalkulus pada masyarakat pesisir yang mengonsumsi air sumur gali di desa Gangga II kecamatan Likupang Barat kabupaten Minahasa Utara. Penelitian ini berupa penelitian deskriptif dengan pendekatan cross sectional study. Pengambilan sampel menggunakan teknik simple random sampling dengan jumlah sampel 272 orang yang masih mengkonsumsi air sumur gali sebagai sumber air minum utama. Data hasil penelitian dikelompokan berdasarkan kelompok umur, jenis kelamin dan skor indeks kalkulus. Hasil penelitian angka kejadian kalkulus di desa Gangga II dengan kategori baik berjumlah 176 orang (64,70\%), kategori sedang berjumlah 88 orang (32,35\%), kategori buruk 8 orang (2,94\%). Hal ini menunjukkan angka kejadian kalkulus pada populasi masyarakat di desa Gangga II termasuk kategori yang cukup baik.
\end{abstract}

Kata kunci: Kalkulus, air sumur gali, masyrakat pesisir.

Kesehatan gigi dan mulut di Indonesia masih kurang mendapat perhatian baik dari pemerintah maupun kalangan masyarakat. Berdasarkan data Kementerian Kesehatan Republik Indonesia, Riset Kesehatan Dasar tahun 2007, prevalensi masalah kesehatan gigi dan mulut sebesar 43,3\%. Masalah kesehatan gigi dan mulut terdapat pada daern ah penyangga gigi, dan salah satu penyebab dari penyakit daerah penyangga 
gigi adalah akumulasi kalkulus. ${ }^{1}$

Kalkulus merupakan kumpulan plak yang mengalami kalsifikasi dan melekat erat pada permukaan gigi serta objek solid lainnya di dalam mulut, sehingga gigi menjadi kasar dan terasa tebal. ${ }^{2}$ Kalkulus terbentuk oleh adanya pengendapan sisa makanan dengan air ludah serta kumankuman maka terjadilah proses pengapuran yang lama kelamaan menjadi keras. Kalkulus yang terus dibiarkan di dalam mulut dapat menyebabkan iritasi, radang pada gusi dan kerusakan pada jaringan penyangga gigi, serta dapat mengakibatkan gigi menjadi goyang dan lepas dengan sendirinya. Komponen pembentukan kalkulus terdiri dari bahan-bahan mineral seperti kalsium dan fosfor. ${ }^{3,4}$

Indonesia merupakan negara kepulauan yang banyak memiliki daerah pesisir pantai. Masyarakat yang tinggal di pesisir pantai tidak mendapatkan sumber air minum dari Perusahaan Air Minum (PAM), sehingga mereka mengonsumsi air sumur gali sebagai sumber air minum utamanya. Air sumur gali yang terdapat di daerah pesisir mengandung derajat keasaman $(\mathrm{pH})$ yang cukup tinggi. Tingginya derajat keasaman ini berpengaruh terhadap jumlah kalsium dan fosfor yang merupakan bahan dalam proses pembentukan kalkulus. ${ }^{5,6}$

Standar normal kalsium dalam air minum yaitu $100 \mathrm{mg} /$ liter air. Konsentrasi kalsium pada air minum yang melebihi standar apabila terus dikonsumsi dapat menambah kepekatan air ludah sehingga kalsium dan fosfor akan membentuk pengapuran dan menjadi kalkulus. ${ }^{6}$ Masyarakat daerah pesisir pantai yang mengonsumsi air sumur gali cenderung memiliki kalkulis dalam mulut ${ }^{7}$.

Desa Gangga II yang terletak di kecamatan Likupang Barat kabupaten Minahasa Utara merupakan desa yang terletak di daerah pesisir pantai. Berdasarkan dari hasil survei awal yang dilakukan penulis, sebagian masyarakat di desa Gangga II masih mengonsumsi air sumur gali sebagai sumber air minum utama.
Berdasarkan latar belakang di atas penulis tertarik melakukan penelitian untuk mendapatkan gambaran kalkulus pada masyarakat yang mengonsumsi air sumur di desa Gangga II.

\section{BAHAN DAN METODE}

Penelitian ini menggunakan jenis penelitian deskriptif dengan menggunakan study cross sectional yang dilaksanakan di desa Gangga II, kecamatan Likupang Barat kabupaten Minahasa Utara, provinsi Sulawesi Utara selama tiga hari pada minggu ke empat bulan Juli 2013. Populasi dalam penelitian ini ialah masyarakat dengan kriteria remaja dan dewasa berusia 12-45 tahun di daerah pesisir pantai desa Gangga II, yang berdasarkan survei awal berjumlah 852 jiwa. Kriteria inklusi yaitu, masyarakat dengan umur 12-45 tahun, masyarakat bersedia untuk dijadikan subjek dalam penelitian ini dengan menandatangani informed consent. Kriteria ekslusi, masyarakat tidak ada saat melakukan penelitian dan masyarakat yang telah kehilang seluruh gigi.

Berdasarkan besar sampel yang diperoleh ditentukan dengan menggunakan rumus Slovin $^{19}$ yaitu barjumlah 272 orang, jadi tektnik pengambilan sampel menggunakan teknik purposive sampling. Teknik pengambilan sampel dengan cara (purposive sampling) yaitu, pengambilan sample secara sengaja sesuai persyaratan yang diperlukan, dengan menggunakan Pemeriksaan indeks kalkulus dilakukan dengan cara menjalankan sonde dari arah incisal atau oklusal ke arah servikal. Nilai nol menandakan tidak terdapat kalkulus, nilai satu menandakan kalkulus menutup tidak lebih dari 1/3 servikal, nilai dua menandakan kalkulus menutup lebih dari $1 / 3$ servikal, nilai tiga menandakan kalkulus menutup lebih dari 2/3 servikal $^{2}$ (Gambar 1 ).

Penelitian ini dilakukan dengan survei awal dan mendapat ijin terlebih dahulu dari Kepala desa Gangga II. Data Primer diperoleh dengan Data karateristik subjek penelitian berupa data nama, umur, jenis kelamin, alamat yang dicatat pada formulir 
Wungkana, Kepel, Wicaksono; Gambaran Kalkulus pada Masyarakat...

pemeriksaan; dan data pemeriksaan klinis, data yang dikumpulkan pada pemeriksaan klinis dengan melihat kondisi kalkulus subjek penelitian.

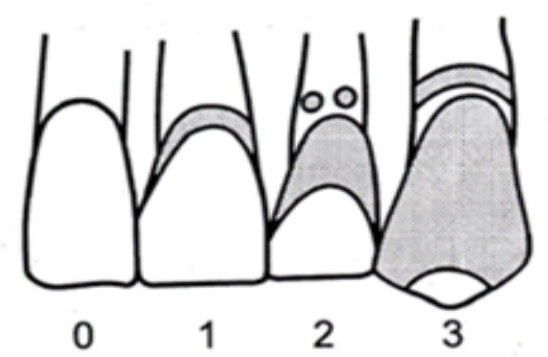

Gambar 1. Skor kalkulus pada pemeriksaan kebersihan mulut menurut indeks Kalkulus ${ }^{2}$

Data dicatat pada formulir pemeriksaan yang sudah disiapkan terlebih dahulu. Kemudian data sekunder, diperoleh dari data jumlah penduduk dilakukan pada awal pemeriksaan, dimana data diperoleh dari pihak kelurahan desa Gangga II.

\section{HASIL}

\section{Profil Desa Gangga II}

Penelitian ini dilakukan di daerah pesisir pantai desa Gangga II yang terletak di kecamatan Likupang Barat, kabupaten Minahasa Utara provinsi Sulawesi Utara. Desa Gangga II merupakan salah satu desa di wilayah kepulauan yang berbatasan dengan desa Tambun di sebelah utara, desa Gangga I di sebelah selatan, pulau Bangka di sebelah Timur, dan laut Sulawesi di sebelah Barat. Wilayah desa Gangga II dengan jumlah penduduk 852 jiwa terbagi berdasarkan 4 wilayah jaga, keadaan penduduk dapat dikategorikan sebagai masyarakat majemuk yang terdiri dari beberapa suku diantaranya suku Ternate, Tidore, Sangihe, Bolaang Mongondow, Minahasa dan Gorontalo. Mayoritas penduduk desa Gangga II bekerja sebagai nelayan dan petani. $^{7}$

Sarana kesehatan gigi di desa Gangga II belum memadai karena tidak adanya puskesmas, hanya ada puskesdes, dan belum memiliki tenaga dokter gigi dan perawat gigi.

\section{Karateristik responden}

Responden pada penelitian ini didistribusikan berdasarkan umur dan jenis kelamin. Pada Gambar 2 berikut ini dapat dilihat diagram distribusi frekuensi responden berdasarkan jenis kelamin.

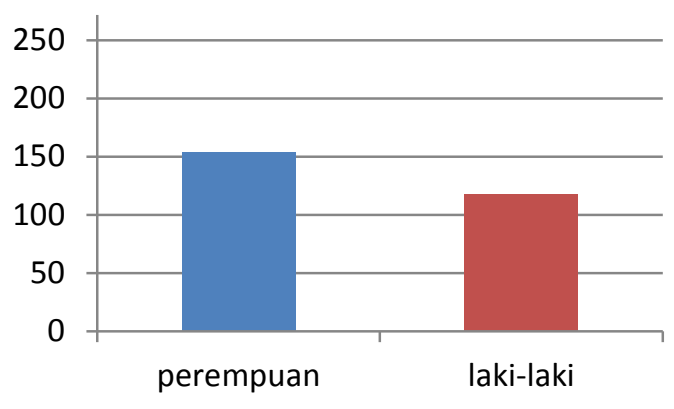

Gambar 2. Diagram distribusi frekuensi responden berdasarkan jenis kelamin

Gambar di atas menunjukkan bahwa responden berjenis kelamin perempuan berjumlah 154 orang (56,98\%) lebih banyak dari responden laki-laki yang berjumlah 117 orang (43,01\%).

Gambar 3 berikut ini menunjukkan distribusi frekuensi responden berdasarkan kelompok umur.

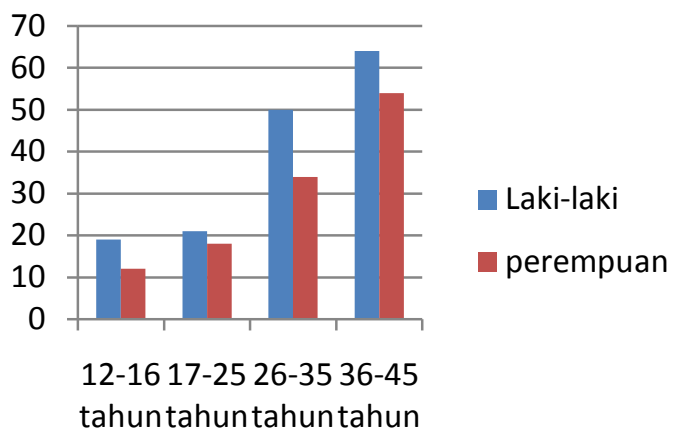

Gambar 3. Diagram Distribusi frekuensi responden berdasarkan kelompok umur

Gambar 3 menunjukkan bahwa pada kelompok umur 12-16 tahun, responden 
berjenis kelamin perempuan sejumlah 19 orang $(7 \%)$ dan responden berjenis kelamin laki-laki sejumlah 12 orang (4,4\%); pada kelompok umur 17-25 tahun terdapat responden berjenis kelamin perempuan sejumlah 21 orang $(7,7 \%)$ dan berjenis kelamin laki-laki sejumlah 18 orang $(6,6 \%)$; pada kelompok umur 26-35 tahun terdapat responden berjenis kelamin perempuan sebanyak 50 orang $(18,4 \%)$ dan berjenis kelamin laki-laki berjumlah 34 orang (12,5\%); pada kelompok umur 36-45 tahun terdapat responden berjenis kelamin perempuan sejumlah 64 orang $(23,5 \%)$ dan berjenis kelamin laki-laki sejumlah 54 orang (19,9\%).

Gambar 4 berikut ini menunjukkan hasil penelitian keseluruhan skor indeks kalkulus berdasarkan jenis kelamin.

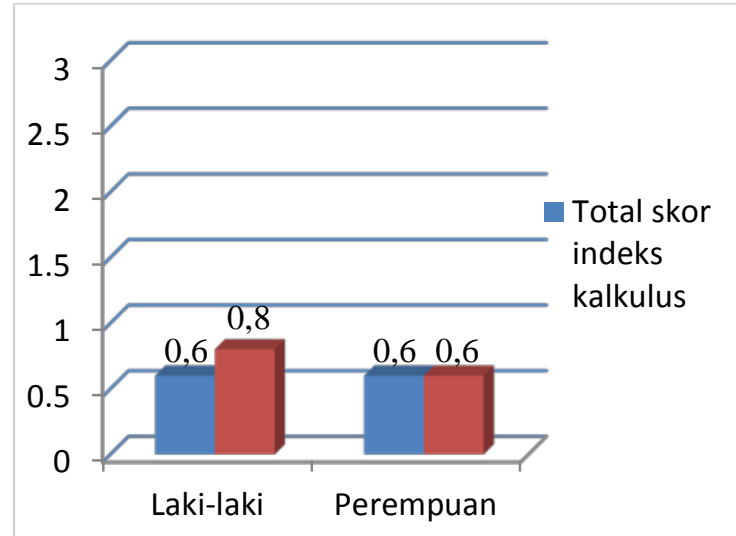

Gambar 4. Diagram distribusi frekuensi skor indeks kalkulus berdasarkan jenis kelamin.

Data diagram pada Gambar 4 menunjukkan bahwa skor indeks kalkulus rata-rata responden nilainya 0,6 dan pada responden berjenis kelamin laki-laki nilainya 0,8 , sedangkan skor indeks kalkulus pada responden berjenis kelamin perempuan nilainya 0,6 .

Gambar 5 berikut ini menunjukkan diagram distribusi frekuensi skor indeks kalkulus responden berdasarkan kelompok umur.

Hasil penelitian sebagaimana ditampilkan pada Gambar 9 menunjukkan bahwa skor indeks kalkulus pada kelompok berumur 12-16 tahun yakni 0,4; pada kelompok umur 17-25 tahun yakni nilainya 0,5; pada kelompok umur 26-35 tahun nilainya sebesar 0,7 dan pada kelompok umur 36-45 tahun nilainya 0,7.

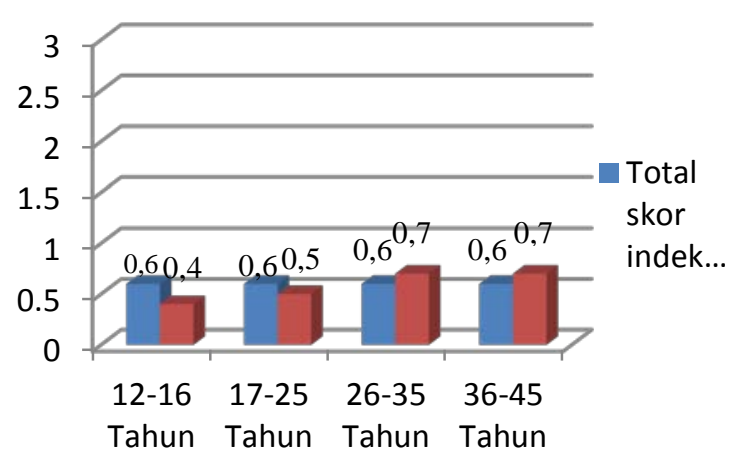

Gambar 5. Diagram distribusi frekuensi skor indeks kalkulus responden berdasarkan kelompok umur

\section{BAHASAN}

Hasil penelitian pada masyarakat desa Gangga II kecamatan Likupang Barat kabupaten Minahasa Utara yang berusia 1245 tahun menunjukkan bahwa angka ratarata skor indeks kalkulus sebesar 0,6, angka ini masuk dalam kategori baik. Skor indeks kalkulus merupakan salah satu skor yang menentukan status kebersihan mulut individu atau masyarakat. Status kebersihan mulut sebagaimana halnya dengan status kesehatan, ditentukan oleh beberapa faktor meliputi faktor lingkungan, perilaku, herediter, dan faktor pelayanan kesehatan. ${ }^{8}$

Faktor lingkungan terbagi atas dua bagian yaitu lingkungan luar mulut dan lingkungan dalam mulut. Lingkungan luar mulut mencakup lingkungn fisik antara lain sumber air bersih. Hingga saat ini masyarakat desa Gangga II masih menggunakan air sumur gali sebagai sumber utama air minum. Kandungan air minum yang memenuhi syarat kesehatan diatur dalam penyediaan air bersih khususnya air minum harus sesuai dengan standar peraturan Menteri Kesehatan Republik Indonesia Nomor 492/MENKES/PER/IV/2010 tentang pengawasan kualitas air bersih. Air minum yang dikonsumsi seharusnya mengandung 
unsur-unsur mineral tertentu, termasuk kalsium dan fosfor. Kalsium dan fosfor yang merupakan salah satu komponen yang juga terkandung dalam air sumur gali. ${ }^{9-11}$

Pada hasil pemeriksaan dan analisa laboratorium 2 sampel air yang dikonsumsi masyarakat desa Gangga II dan diambil dari 2 sumber air yang berbeda, menunjukkan kadar kandungan mineral kalsium dan fosfor yang berbeda. Kandungan kalsiumnya sebesar 62,21 $\mathrm{mg} / \mathrm{L}$ air dan kandungan fosfor sebesar $0,0487 \mathrm{mg} / \mathrm{L}$ air. Hasil ini berada di bawah standar normal kandungan kalsium yang harus terdapat dalam air minum, yakni $100 \mathrm{mg} / \mathrm{L}$ air. Kandungan mineral dalam air tanah dipengaruhi antara lain oleh adanya aktivitas vulkanik kedalaman sumur gali di wilayah tersebut. Kedalaman air sumur gali juga dapat memengaruhi kandungan mineral kalsium dan fosfor dalam air tanah. ${ }^{12}$ Berdasarkan pengamatan yang dilakukan peneliti, tampak bahwa kedalaman sumur gali di desa Gangga II umumnya tidak begitu dalam. Semakin dalam galian tanah, maka kemungkinan semakin tinggi juga kadar mineral yang terlarut dalam air. Penulis berpendapat bahwa kedalaman air sumur gali desa Gangga II yang cukup rendah, memungkinkan kadar mineral yang terlarut di dalam air sumur gali jumlahnya kecil. Pada penelitian ini peneliti memiliki keterbatasan yakni tidak melakukan pengukuran kedalaman sumur gali secara pasti, namun hanya berdasarkan perkiraan dari kondisi sumur yang tampak saat dilakukan penelitian.

Kalkulus merupakan kumpulan plak yang mengalami kalsifikasi dan melekat erat pada permukaan gigi serta objek solid lainnya di dalam mulut, sehingga gigi menjadi kasar dan terasa tebal. ${ }^{2}$ Kalkulus terbentuk oleh adanya pengendapan sisa makanan dengan air ludah serta kumankuman maka terjadilah proses pengapuran yang lama kelamaan menjadi keras. Komponen pembentukkan kalkulus antara lain terdiri dari bahan-bahan mineral seperti kalsium dan fosfor dimana kandungan tersebut juga terkandung pada air sumur gali. ${ }^{13}$ Asupan air minum yang berasal dari air sumur atau air tanah merupakan sumber kalsium dan fosfor dalam pembentukan kalkulus, di samping berasal dari sisa makanan yang dikonsumsi dan menempel pada permukaan gigi. ${ }^{7}$ Pada penelitian ini peneliti berpendapat sumber kalsium dan fosfor yang berperan dalam pembentukan kalkulus pada masyarakat desa Gangga II bukan berasal dari air yang dikonsumsi. Kalsium dan fosfor yang berperan dalam pembentukan kalkulus kemungkinan berasal dari diet. Sisa makanan yang banyak mengandung kalsium dan fosfor, dan tertinggal pada permukaan gigi akibat kurangnya kebersihan mulut masyarakat, lama kelamaan akan mengapur. ${ }^{26} \mathrm{Di}$ samping itu keadaan ini bisa juga dipengaruhi oleh kondisi lokal dalam mulut responden. Kondisi saliva yang dapat memengaruhi pembentukan kalkulus yakni saliva yang konsistensinya kental.

Pada rongga mulut umumnya terdapat lapisan saliva setebal 0,1-0,01 mm yang melapisi seluruh jaringan rongga mulut. Semakin kental saliva dalam mulut akan membantu pengendapan mineral kalsium dan fosfor hingga terbentuknya kalkulus. ${ }^{15}$ Desa Gangga II merupakan daerah yang berada di pesisir pantai, dimana masyarakatnya lebih banyak mengonsumsi hasil laut sebagai makanan sehari-hari. Makanan laut lebih banyak memiliki kandungan mineral kalsium dan fosfor dibandingkan jenis makanan lainya. Penulis berasumsi bahwa sisa makanan yang dikonsumsi dan mengandung mineral kalsium serta fosfor dan menempel pada permukaan gigi dapat berpengaruh terhadap pembentukan kalkulus.

Berdasarkan pengamatan penulis, tampak bahwa perekonomian masyakarakat desa Gangga II saat ini masih rendah, dimana sebagian besar masyarakat desa bekerja sebagai nelayan dan berjualan di pasar. Penghasilan yang diperoleh terbilang kecil, sehingga kondisi ini mungkin sturut memengaruhi perilaku masyarakat desa Gangga II dalam pemeliharan kesehatan gigi dan mulutnya.

Pembentukan kalkulus secara tidak langsung dapat juga dipengaruhi oleh faktor 
pengetahuan. Pengetahuan masyarakat yang cukup memadai dalam pemeliharaan kebersihan gigi dan mulut dapat menurunkan risiko pembentukan kalkulus. ${ }^{27}$ Kondisi kalkulus masyarakat desa gangga II cukup baik. penulis berpendapat hal ini dikarenakan masyarakat desa Gangga II sudah mendapat penyuluhuhan tentang kesehatan tenganng gigi dan mulut dari. Kegiatan penyuluhan kesehatan gigi dan mulut di desa Gangga II cukup sering dilakukan oleh institusi kesehatan, ataupun oleh para relawan.

Secara teori dikatakan bahwa faktor herediter dapat merupakan salah satu faktor yang juga mempengaruhi status kesehatan termasuk status kebersihan mulut. ${ }^{28}$ Pada penelitian ini penulis melihat bahwa faktor ini sangat kecil pengaruhnya, kalaupun ada dapat dilihat kaitannya pada responden yang memiliki susunan gigi yang tidak beraturan sehingga memungkinkan sisa makanan terakumulasi dan merupakan salah satu faktor risiko pada pembentukan kalkulus.

\section{SIMPULAN}

Berdasarkan hasil penelitian yang dilakukan diperoleh kesimpulan bahwa gambaran kalkulus pada masyarakat Desa Gangga II berada pada kategori baik, dengan hasil pengukuran skor indeks kalkulus 0,6.

\section{SARAN}

Perlu adanya kerjasama dan dukungan pemerintah dalam penyediaan puskesdes dan tenaga kesehatan gigi yang menetap di desa Gangga II sehingga terjadi pemerataan pelayanan kesehatan gigi dan mulut.

Perlu adanya upaya penyuluhan kesehatan gigi dan mulut secara berkala sehingga status kesehatan gigi dan mulut masyarakat yang sudah baik dapat dipertahankan atau lebih ditingkatkan lagi.

\section{DAFTAR PUSTAKA}

1. Badan Peneliti dan Pengembangan Kesehatan RI. Laporan hasil reset keesehatan dasar nasional tahun 2007.
Jakarta: Departemen Kesehatan RI; 2008. H

2. Putri MH, Herijulianti.E, Nurjannah.N. Ilmu pencegahan penyakit jaringan keras dan jaringan pendukung gigi. Jakarta: EGC. 2010: h. 85-9.

3. Tungga DM. Hubungan kandungan kapur dalam air minum dengan pembentukan indeks kalkulus pada siswa usia 12-14 tahun di SMP Negeri 2 Soko,Tuban. Universitas Brawijaya. 2011

4. Astuti FY. Penelitian pengaruh kehamilan terhadap kesehatan periodontal. Sei rampah : Universitas Sumatra Utara. 2009. h. 13

5. Widya Ch, Nuryetty MT, Sumarningsih.D, Winarti YG, Ariewidayanti D, Harisah R. Indikator kesejahteraan masyarakat kelautan dan perikanan 2011. KKPRI.2012 : h. 5

6. Yusuf.Y, Nisma.F, Rusdi NK. Analisis kandungan air sumur warga RT 12,17 dan 18 RW 09 kelurahan Kelapa Dua Watan kecamatan Ciracas Jakarta timur.2011.

7. Pemerintah kabupaten Minahasa Utara kecamatan Likupang Barat desa Gangga II. Manado 2013

8. Theresia. Perbandingan oral hygiene dan pengetahuan antara kelompok satu kali dan penyuluhan dan kelompok dua kali penyuluhan kesehatan gigi dan mulut pada penderita tunanetra usia $12-19$ tahun di medan. Universitas Sumatra Utara. 2010.

9. Amaliyah KI. Hubungan sumber air dengan deposit kalkulus pada masyarakat dikecamatan Maros baru kabupaten Maros. Universitas Hasanudin. 2011.

10. Sekeon AS. Gambaran pelayanan kesehatan di wilayah kerja puskesmas Tamakao kabupaten kepulauan Sangihe Sulawesi Utara. [Skripsi] Universitas Sam Ratulangi. 2004.

11. Ritonga L. Pelaksanaan Program upaya kesehatan gigi di puskesmas Padang Bulan dalam meningkatkan derjat kesehatan masyarakat. Universitas Sumatera utara. 2011. h.14

12. Mahyun S. Analisis kualitas air laut berdasarkan parameter fisika dan kimia serta kandungan logam berat di kawasan industri pesisir pantai Sibolga. Universitas Negeri Medan. 2012.

13. Newman MG, DDS, Takei. HH, DDS. MS ; Carranza.F.A Dr Odont. Clinical periodontologi : 2003 : p.182-8.

14. Anitasari S. Hubungan frekuensi menyikat gigi dengan tingkat kebersihan gigi dan mulut siswa sekolah dasar negeri di kecamatan Palaran kotamadya Samarinda 
Wungkana, Kepel, Wicaksono; Gambaran Kalkulus pada Masyarakat...

provinsi Kalimantan Timur. Universitas Mulawarman. 2005.

15. Gudang ilmu gigi. Mekanisme terbentuknya plak dan kalkulus. [online] Available from URL:

file://C:/Users/Public/Documents/yg\%20m \%20d\%20prin/_\%20GUDANG\%20ILMU\% 20GIGI.htm. Accessed Juni1.2014.

16. Ambo Rustan. Kesehatan gigi dan dampak sosialnya. [online] Available from URL : http://kesehatan.kompasiana.com/meis/2010 /11/23.kesehatan-gigi-dan-dampaksosialnya-catatan-dari-maratua320506.html. Accessed Juni 2014.

17. Purba TR. Perilaku kebersihan gigi dan perbedaan status oral higiene murid kelas $\mathrm{V}$ SD di daerah rural kecamatan Pantai Cermin dan daerah urban kecamatan Medan Barat. [Skripsi] Universitas Sumatera Utara.2009. 